\title{
The instrumental signals of the Eurasian Wryneck (Jynx torquilla)
}

\author{
Kyle TuRner ${ }^{1} \&$ Gerard GORMAn $^{2 *}$
}

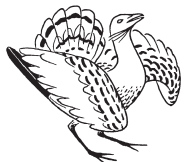

Received: February 21, 2021 -Revised: April 12, 2021 -Accepted: April 14, 2021

Turner, K. \& Gorman, G. 2021. The instrumental signals of the Eurasian Wryneck (Jynx torquilla). - Ornis Hungarica 29 (1): 98-107. DOI: 10.2478/orhu-2021-0007

\begin{abstract}
In a study of acoustic communication at seven nest cavities of Eurasian Wrynecks, sound recordings were made of ninety-one separate bursts of tapping. From Hungary in the east, and France in the west, tapping was heard both from inside cavities and at their entrances. Analysis of the tapping rhythms indicated two forms corresponding to different observed behaviour. They were never loud and were used exclusively in communication between breeding pairs. No functional significance was found in the only two brief examples of tapping fast enough to be described structurally as drumming.
\end{abstract}

Keywords: communication, tapping, drumming, nest cavities, wryneck, woodpeckers, spectrogram

Összefoglalás Ebben az akusztikus kommunikációval foglalkozó kutatásban hét nyaktekercs fészekodúnál 91 különálló kopogás egységről készült hangfelvétel. Keleten (Magyarország) és nyugaton (Franciaország) a kopogást az üregek belsejéből és a bejáratnál is lehetett hallani. A kopogás ritmusának analízise két formát mutatott ki, amelyek különböző megfigyelt viselkedéseknek feleltek meg. Sosem voltak hangosak, és kizárólag a költő pár közötti kommunikációban használták azokat. Nem találtunk funkcionális jelentőséget a csupán két rövid példa esetében, amikor a kopogás olyan gyors volt, hogy szerkezetileg dobolásként lehetett leírni.

Kulcsszavak: kommunikáció, kopogás, dobolás, fészekodúk, nyaktekercs, harkályok, spektogram

${ }^{1}$ Independent Bio-acoustics Researcher, St. Andrews Farm, Woodbridge Lane, Bedchester, Shaftesbury, Dorset, SP7 OBF. United Kingdom

${ }^{2}$ Independent Picidae Researcher, Hungarian Woodpecker Working Group, MME/Birdlife Hungary, 1121, Budapest, Költö utca 21, Hungary

*corresponding author, e-mail: picidae.gerard@gmail.com

\section{Introduction}

The Eurasian Wryneck (Jynx torquilla) is often regarded as an aberrant woodpecker, as in several aspects of its anatomy and morphology, it is the least typical of the eleven species in the Picidae family that breed in Europe. It is the only member, for example, that is truly migratory (most European breeding populations winter in sub-Saharan Africa), to have cryptic colouration, to have a relatively small head and long tail, to perch rather than climb, and to have a weak, passerine-like bill (Goodge 1972). Indeed, this species lacks many of the structural features typical of true woodpeckers (Picinae) that facilitate a physical ability to bore deep into wood to find invertebrate prey and fully excavate a nest cavity. The species is not sexually dimorphic and in most cases males and females are inseparable.

The Eurasian Wryneck has an exclusively Old-World distribution, occurring in parts of Europe, Asia and Africa (Gorman 2014). It is polytypic, with taxonomists recognising from four 
to seven subspecies (Winkler et al. 1995, del Hoyo \& Collar 2014, Clements et al. 2019, Gill et al. 2020). Although the overall global population is suspected to be in decline, the species is not considered to be vulnerable or seriously threatened as it occurs over a vast range. Therefore, in the IUCN's Red List of species, it is categorised as Least Concern (BirdLife 2021).

Ringing recoveries in Europe suggest two probable migration routes, with birds from the north and west passing through Iberia and birds from further east travelling through Italy and the Balkans (Reichlin et al. 2009). The return to breeding areas in spring marks a peak of vocal activity, while both males and females seek potential nest sites. Persistent advertising, in the form of song, leads to the inspection of cavities by both birds and to courtship, which is accompanied by a range of soft, intimate calls (Ruge 1971). At this stage, although they do not excavate a complete cavity, birds may undertake some light, peripheral improvement of an existing one.

Some previous observers have suggested an instrumental function to tapping at the cavity entrance, such as when showing a potential nest site and when birds arrive for nest relief. Short (1982), referencing Witherby et al. (1938), wrote that the species sometimes drums 'woodpeckerlike, but weakly, slowly, and not audible at any distance', and 'drums weakly and infrequently in slow series' (1988). 'Drumming' inside the cavity as birds prepared to nest is mentioned by Puhlmann (1914). Tapping and 'drumming' on cavity walls and at the entrance are mentioned as taking place, when birds inspect and modify cavities, by Glutz von Blotzheim and Bauer (1994). The same authors also mention tapping with a rhythmic start that ends in a uniform roll on a branch away from the nest, but this behaviour is seldom observed and unpredictable (Gorman 2004). Wimmer and Zahner (2010) refer to soft 'tapping and drumming' when showing a nest cavity. More specifically, Schneider (1961) described four rolls ranging from six to ten strikes given by a bird at the entrance to a nest box in response to the arrival of a second bird.

Ruge (1971), however, defines such sounds as 'demonstrative tapping' or 'rhythmic tapping'. Due to the lack of any recorded examples, Eurasian Wryneck was not included in statistical comparisons of drumming by European woodpeckers (Zabka 1980, Florentin et al. 2016). In addition, Menzel (1968), Winkler et al. (1995) and González et al. (2002) do not detail any instrumental sounds for the species in their works. Whereas instrumental tapping has been described in all of the European Picidae (Cramp 1985), a behavioural comparison using measured examples, including Eurasian Wryneck, has yet to be published (Florentin et al. in prep.).

The aim of this paper was to analyse recent sound recordings of the instrumental signals produced by Eurasian Wrynecks with their bills, and to establish a better understanding of their structure and function. In addition, we sought to clarify the terminology used by previous authors on this subject, which in some cases is ambiguous.

\section{Method and Materials}

The recordings used in this study were made in two areas of Europe, Hungary and France. In Hungary, pairs were observed in the remnants of orchards bordering villages in the Bükk National Park $\left(48.048^{\circ} \mathrm{N} 20.528^{\circ} \mathrm{E}\right)$. In France, pairs were observed in old false acacia 
(Robinia pseudoacacia) scrub on a sheep grazed limestone plateau in the Parc Naturel Régional des Causses du Quercy $\left(44.385^{\circ} \mathrm{N}, 1.342^{\circ} \mathrm{E}\right)$. Recordings were made in both areas from April to June covering the period of pair establishment and breeding. We placed microphones close to potential nest sites because this is the only reliable method of collecting instrumental sounds from this species. No examples of instrumental recordings for Eurasian Wryneck were found by searching other resources, such as the internet site xeno-canto.org. The only examples available came from a wide-ranging study of the acoustic signals of European woodpeckers (Turner unpub.).

We used a range of equipment: a pair of Sennheiser MKH 105 omnidirectional condenser microphones in an Atherstone $50 \times 13 \mathrm{~cm}$ parabolic reflector into a Kenwood DMC-G7R Minidisc recorder @ 44.1kHz/16bit (Atrac 4.5) and a pair of Sennheiser MKH 60 (short gun) condenser microphones into a Sound Devices 722 file recorder @ 44.1kHz/16bit. Reflector recordings were made at a distance of approximately seven metres and the open microphones were placed at about four metres from the nest cavity. Behaviour was observed though binoculars from between seven and ten metres. Sound editing was carried out using Cool Edit Pro II software, with spectrograms produced on Raven Lite (Cornell). Strike counts were extracted manually from spectrograms and average strike interval lengths were measured to the nearest millisecond, as employed in studies of drum-roll patterns (Zabka 1980, Florentin et al. 2016), using Microsoft Excel 2016.

We employed the following terms: 'instrumental' to mean a non-vocal sound used as a signal, 'rhythmical' to mean evenly spaced or smoothly accelerating/decelerating, 'strike' to mean an individual acoustic impact showing as a spike on a spectrogram, 'burst' to mean a distinct grouping of similarly spaced strikes having an average interval of more than $90 \mathrm{~ms}$, 'roll' to mean a distinct grouping of similarly spaced strikes having an average interval of less than $90 \mathrm{~ms}$. An average strike speed slower than this falls outside the range for drumrolls encountered among European woodpeckers (Zabka 1980, Florentin et al. 2016, Turner 2020), and is therefore treated as instrumental tapping.

Gaps separating bursts of tapping were set at a minimum of 200 milliseconds, beyond which there was an audible pause in the tapping rhythm. Slower tapping speeds were associated with cavity modification. Sounds resulting from this activity typically had a more erratic strike rate in both rhythm and strength coupled with angled strikes sounding more like tearing, which resulted in double spikes on spectrograms. These sounds, paralleling those of excavation in other woodpeckers, were not treated as instrumental signals and were thus disregarded.

\section{Results}

Twenty-three recordings of sequences containing instrumental tapping were made, at five nest sites in France and two in Hungary, between 2001 and 2013 (Table 1). Twelve of these were made at one nest in Hungary during a concentrated effort of 14 hours over seven days at the start of June 2007. Tapping bursts, consisting of the evenly or smoothly spaced strikes typical of instrumental signals, were given when both members of the pair were present: 
Table 1. Dates and regions in which recordings of the Fast and Slow tapping rhythms were made. Number of bursts in brackets. In total, forty-two bursts of fast tapping were recorded at five nests and fifty of slow tapping at four nests, with both forms occurring at two nests

1. táblázat Gyors és lassú ritmusú kopogás felvételeinek dátuma és régiója. Az egységek száma zárójelben szerepel. Összesen negyvenkét egységről készült felvétel, gyors kopogás esetében öt fészeknél és ötven lassú kopogás esetében négy fészeknél, mindkét forma 2 fészeknél fordult elő

\begin{tabular}{|c|c|c|c|c|c|c|}
\hline Year & 2001 & 2003 & 2004 & 2006 & 2007 & 2013 \\
\hline $\begin{array}{l}\text { Fast } \\
\text { Hungary }\end{array}$ & & $\begin{array}{l}6 \text { May } \\
\text { (3) }\end{array}$ & & & $\begin{array}{l}\text { 2/3 June } \\
\text { (15) }\end{array}$ & \\
\hline $\begin{array}{l}\text { Fast } \\
\text { France }\end{array}$ & $\begin{array}{l}\text { 8/13 May } \\
\text { (14) }\end{array}$ & $\begin{array}{l}\text { 20/21 April } \\
\text { (3) }\end{array}$ & $\begin{array}{l}\text { 12/18 April } \\
\text { (5) }\end{array}$ & $\begin{array}{l}28 \text { May } \\
\text { (2) }\end{array}$ & & \\
\hline $\begin{array}{l}\text { Slow } \\
\text { Hungary }\end{array}$ & & $\begin{array}{l}6 \text { May } \\
\text { (2) }\end{array}$ & & & $\begin{array}{l}\text { 2/3 June } \\
\text { (47) }\end{array}$ & \\
\hline $\begin{array}{l}\text { Slow } \\
\text { France }\end{array}$ & & & & & & $\begin{array}{l}12 \text { May } \\
\text { (1) }\end{array}$ \\
\hline
\end{tabular}

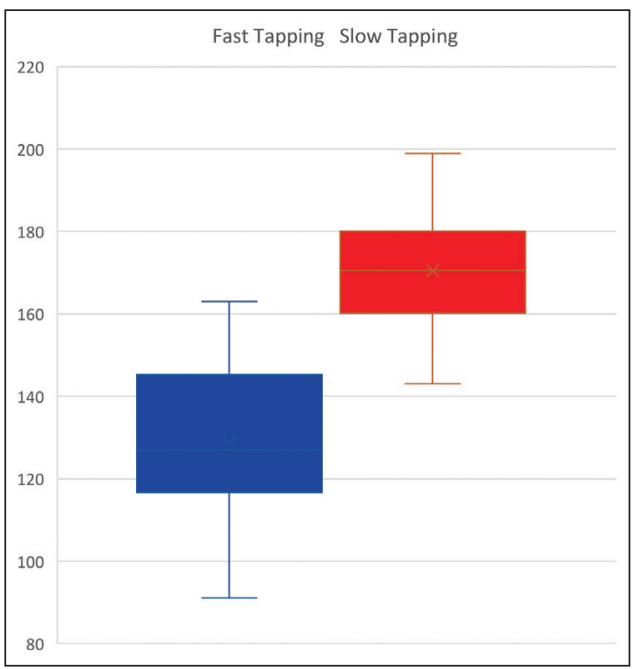

Figure 1. Average strike interval lengths (ms)

1.ábra Átlagos csapások közötti intervallumok hossza (ms)

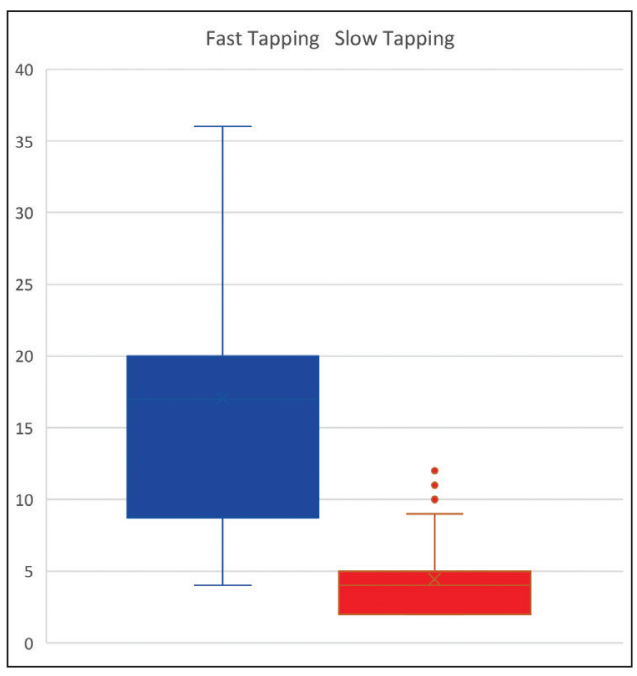

Figure 2. Average number of strikes per burst Fast tapping $(n=42)$. Slow tapping $(n=50)$. One exceptionally long burst of 65 strikes of fast tapping has been omitted

2. ábra A csapások átlagos száma egységenként

Gyors kopogás ( $n=42)$. Lassú kopogás $(n=50)$. Egy kivételesen hosszú, gyors kopogás-egységet, amely 65 csapásból állt, kihagytunk 


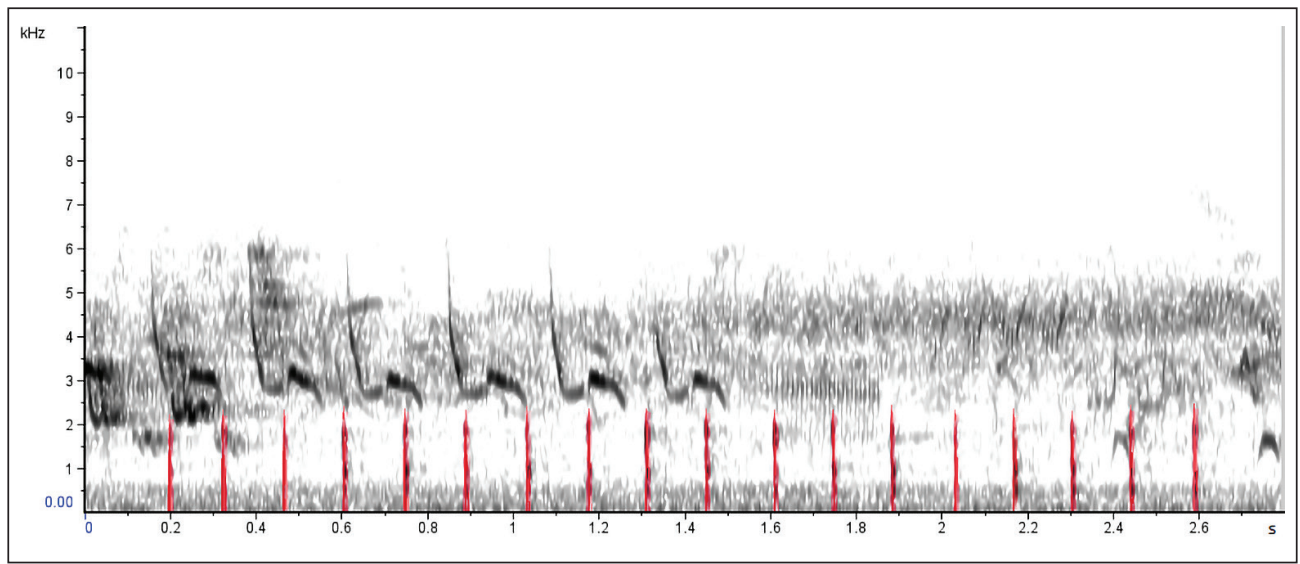

Figure 3. Burst of 18 strikes of fast tapping just inside the cavity, with a very regular interval length of $140 \mathrm{~ms}$. Seven bursts were given in the sequence. France, $13^{\text {th }}$ May 2001

3. ábra 18 csapásból álló gyors kopogás-egység az odú belsejéből, nagyon szabályos 140 ms intervallum hosszúsággal. Hét egység volt egymás után. Franciaország, 2001. május 13.

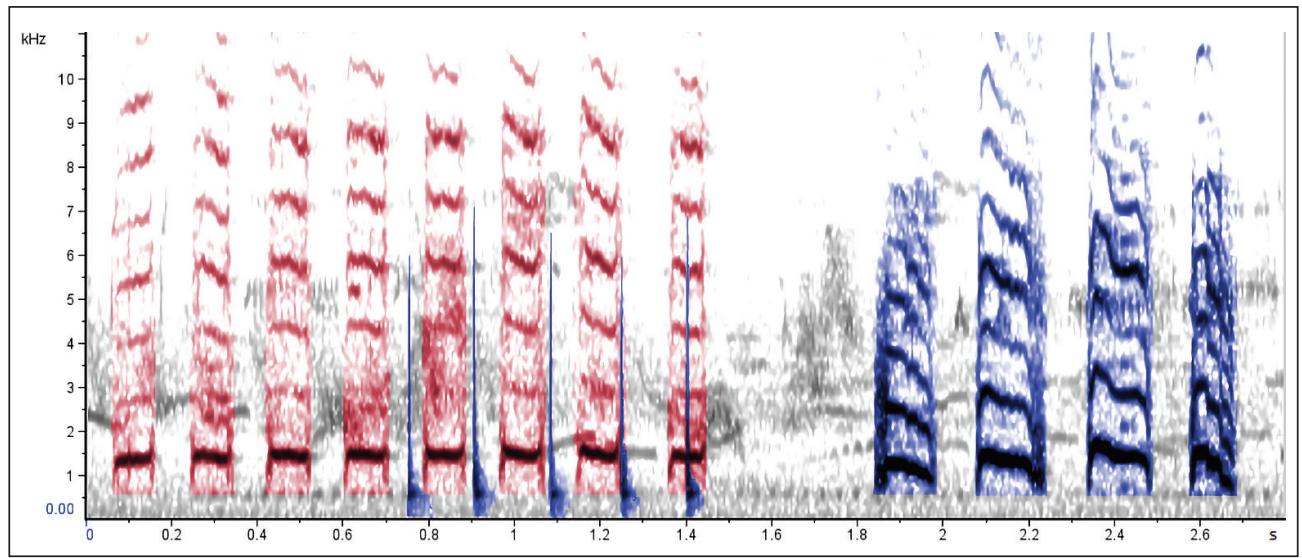

Figure 4. Short burst of slower tapping (5 strikes coloured blue, from 0.75 to $1.41 \mathrm{secs}$.) with average intervals of 162 ms given by one bird outside the cavity entrance during a song duet. The tapping coincides with the mate's song, heard from inside the nest cavity (8 elements, coloured red) and is immediately followed by the first bird's song (4 elements, coloured blue). This combination of slow taps and song came during a nine-minute recording that contained eighteen slow tapping bursts intermixed with thirty-five of excavation by the bird at the nest entrance. In the duet, this bird sang forty-two times and the bird inside fourteen times. Occasional 'vet' calls were given by both birds and one exceptionally soft roll was heard from inside towards the end

4. ábra Rövid egység lassú kopogásból (5 csapás, 0,75-1,41 s) 162 ms átlagos intervallum hosszal, egy madártól az odú bejáratán kívül egy duett során. A kopogás egybeesik a pár énekével, amit az odú belsejéből lehet hallani (8 elem, 0,6-1,44 s), amit azonnal követ az első madár éneke (4 elem, 1,8-2,7 s). Ez a kombinációja a lassú kopogásnak és éneknek egy kilenc perces felvételen szerepelt, amely tizennyolc lassú kopogás egységet tartalmazott összekeveredve harmincöt, az odú bejáratánál végzett vájással. A duett során ez a madár negyvenkétszer énekelt, míg a bent lévő madár tizennégyszer. Alkalmi „vet” hívóhangokat mindkét madár kiadott, és egy nagyon halk, dobpergés-szerű hang volt hallható belülről a vége felé 


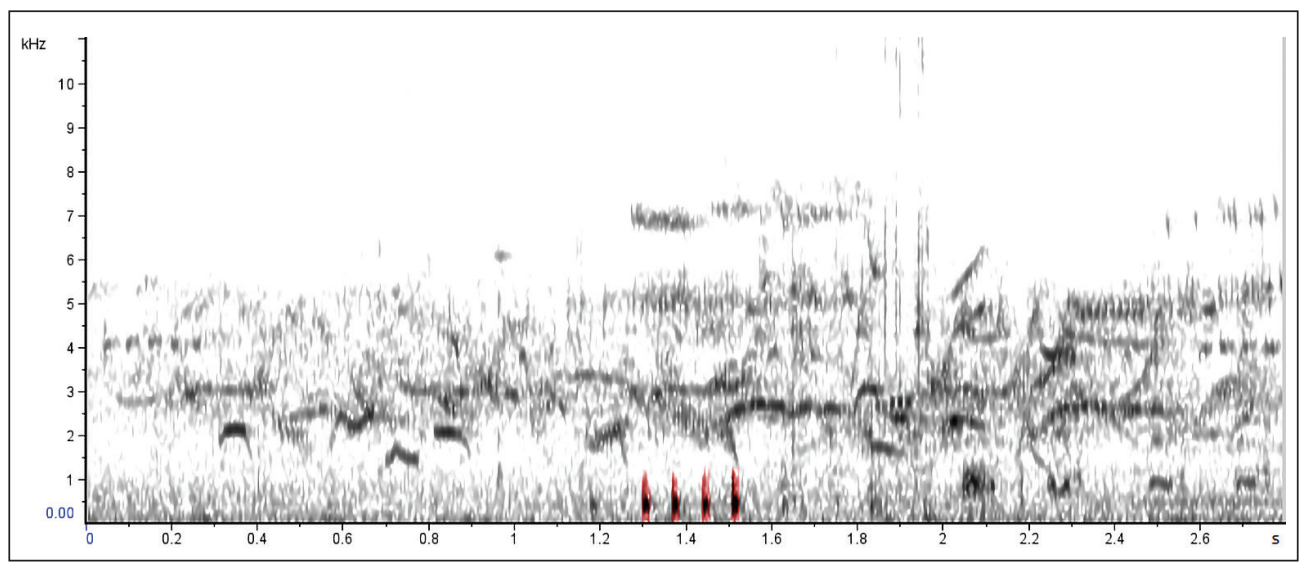

Figure 5. Soft roll, 4 strikes (from 1.3 to 1.52 secs) with average intervals of 69 ms. Given by a bird inside the cavity (from the same sequence as Figure 4 Hungary, $3^{\text {rd }}$ June 2007). Later in the morning, the first nestling calls were heard. This roll was one of only two recorded, both having only four strikes, with average interval lengths of $69 \mathrm{~ms}$ and $72 \mathrm{~ms}$

5. ábra Halk dobpergés-szerű hang, 4 ütés (1,3-1,52 s) 69 ms átlagos intervallummal. Egy odúban lévő madár adta ki (ugyanabból a sorozatból, amelyikből a 4. ábra. Magyarország, 2007. június 3). A délelőtt során később lehetett hallani az első fióka hangokat. Ez a dobpergésszerű hang az egyike volt a csupán kettő felvettnek, mindkettőben csak négy csapás volt, 69 ms és 72 ms intervallum hosszúsággal

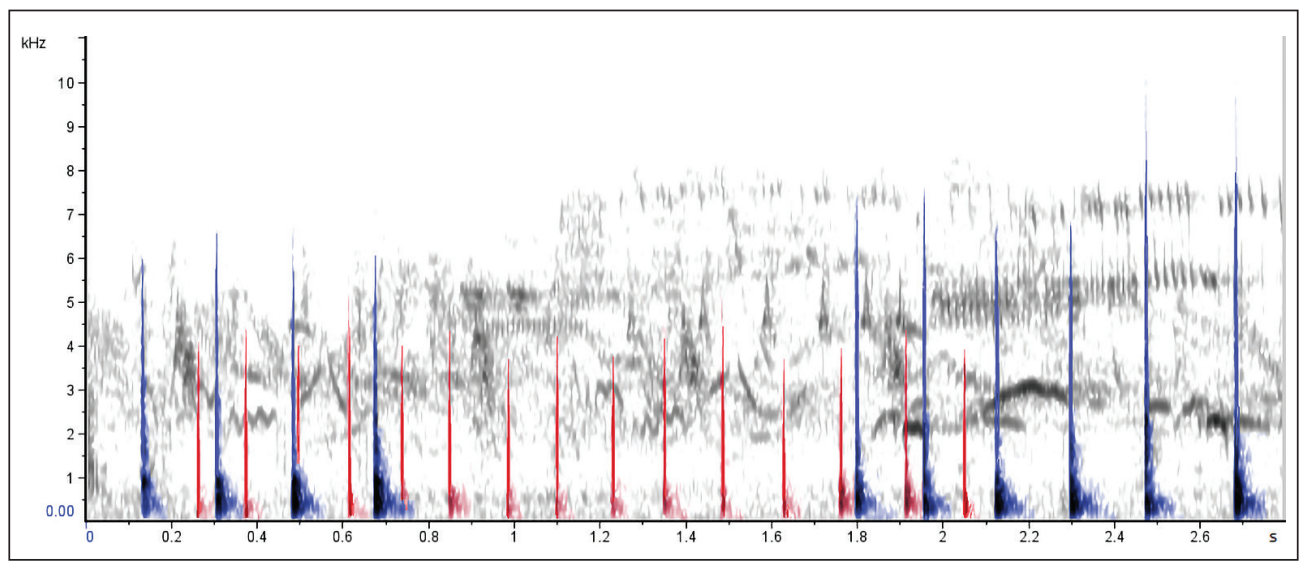

Figure 6. One bird tapping at the nest entrance ( 2 bursts $-4 \& 6$ strikes, coloured blue) at average strike intervals of $179 \mathrm{~ms}$, while the mate replies with faster taps (15, coloured red) from inside the cavity at $126 \mathrm{~ms}$. Hungary $3^{\text {rd }}$ June 2007. The relationship between the structural difference of fast and slow tapping with the functional significance, one form given inside the cavity and the other outside, was clearly illustrated during a 'tapping-duet' where the bursts overlapped

6. ábra Egy madár kopácsol az odú bejáratánál (2 sorozat - 4 és 6 csapás, kék szín), a csapások közötti intervallum átlagosan 179 ms volt, míg a párja gyorsabb kopogással válaszolt (15, piros szín) az odú belsejéből 126 ms-mal. Magyarország, 2007. június 3. A gyors és lassú kopogás szerkezeti különbségének és funkcionális jelentőségének kapcsolata, az egyik az odú belsejéből, a másik kívülről leadva, világosan illusztrálva lett a „kopogás-duett” során, ahol a sorozatok átfedtek 
close to the cavity entrance, at the edge of the entrance, and inside the nest cavity. Two tapping speeds were identified (Figures 1, 2).

Bursts of tapping were faster and longer when the pair were close to each other, forming a component of a courtship ceremony together with soft 'vet' and 'graeb' calls, and short, muted versions of the typical song of the species. Most of these fast bursts were given from deep within the nest chamber, with both birds present inside. However, one sequence was given by a bird just inside the entrance (Figure 3).

Nineteen recordings of courtship were made at the seven nest sites between April and June. Of these, twelve, from five of the sites, included fast tapping. In Hungary, a recording of a courtship sequence made at the time of egg-laying in mid-May, contained no tapping. However, in early June as eggs were starting to hatch, five sequences with tapping were recorded. By contrast, in France, five out of seven courtship sequences that contained tapping were recorded in the middle of April, possibly before eggs were laid. Overall, fourteen sequences containing bursts of fast tapping were recorded, eight in France and six in Hungary, of which five were at the nest in 2007.

All other examples of rhythmical tapping were given externally, by the nest entrance, in shorter, slower bursts. These appeared to signal the presence of the bird in the following situations: as the second bird was moving closer, to its mate already inside the nest (Figures $4,6)$, to its mate which had emerged, or following the 'sgissgissgiss' call when the mate did not respond. This call has been described as given in annoyance when a mate failed to appear for nest relief (Bussmann 1941). Nine sequences containing bursts of slower tapping were recorded, one at a nest in France and eight in Hungary, with seven at the nest in 2007.

An analysis of average strike intervals and number of strikes per burst enabled a comparison of relative speed and burst length for the two tapping rhythms (see Figures 1,2).

Double or triple taps were regularly heard but did not appear to have a different significance from the slower form and were frequently incorporated into longer sequences, with similar strike interval lengths to the longer bursts. One example of a double tap was given on exiting the cavity after feeding newly hatched young, and a triple tap was given in immediate response to its mate's song.

\section{Discussion}

We found that breeding pairs of Wryneck used tapping as a means of communication at nest sites. Two speeds were observed, with a faster form given by one bird inside the cavity during courtship and a slower form given at the entrance. The statistics for strikes per burst from fast tapping inside the nest cavity may not fully reflect the length of the bursts, as these may have been shortened where some strikes were just too soft to hear or were obscured by sounds of other birds outside. Also, some ambiguity remains regarding the separation of slow tapping intended as a signal, from the generally looser pecking involved when Wrynecks modify a cavity entrance. That is, when they are combined in one sequence. This combination is not untypical of other woodpeckers, but the continuation right through to hatching was unexpected, except where it may have been a form of comfort behaviour. 
In most European woodpeckers, instrumental tapping has been identified in two behavioural contexts; to signal either a potential nest site or, when a cavity is in use, readiness to changeover during excavation, incubation or brooding. Such communication is most ritualised in Black Woodpecker (Dryocopus martius) (Blume 1996), which taps rapidly inside the cavity during nest relief. For Eurasian Wryneck, the present study indicates that it uses the fast form as a component of a courtship ceremony, which may be performed at any time from early mating through to egg hatching and also occurs inside the nest. The slower form, given in short bursts, has a parallel with the 'nest showing' signals of so-called pied woodpeckers (Winkler \& Short 1978, Blume \& Tiefenbach 1997). The differences in observed behaviour confirm the significance of a functional separation of the two forms resulting from structural analysis (Zabka 1980) and see Figures 5, 6 above. This is supported by the lack of any examples of slow tapping heard from inside the cavity.

It is interesting to speculate on the similarities between Eurasian Wryneck and the true (Picinae) woodpeckers regarding their evolutionary divergence. The theory that instrumental signals, including eventually drumming, may have evolved from the action of excavation (see for example, discussion in Zabka 1980) would suggest that separation occurred after the development of a strong bill and associated muscles. In this case, Eurasian Wryneck would be evolving away from a common, strong-billed ancestor. And yet, many similarities with the 'true woodpeckers' remain, as with some members of the Melanerpes genus of the Americas where mutual tapping, with one bird inside the cavity and one outside, is typical (Winkler \& Christie 2002).

No substantive evidence was found of the use of drumming, either structurally fast enough to be considered drum-rolls, or functionally serving as signals. The two short rolls heard, barely matched our definition of the term and deviate from the relationship between structure and function associated with most other European woodpeckers (Turner 2020). One hypothetical explanation for the four-strike roll given inside the cavity could be as an intimate 'celebration' of egg hatching (as is done far more loudly, for example, by Black Woodpecker). While Eurasian Wryneck is capable of producing drum-rolls of sorts, we consider that with its fine-tipped, weak bill, it is not equipped to perform 'drumming' in the true sense, to loudly advertise territory as other woodpeckers do. Rather, it 'taps energetically with the bill within and around the nesting cavity' (Gorman 2004). We agree with Ruge et al. (1988) that Eurasian Wrynecks do not genuinely 'drum' and that the instrumental signals of this species are more accurately described as 'demonstrative' or 'rhythmical tapping'.

\section{Conclusion}

With statistical reliability limited by the available data, we believe that this study has nevertheless presented clear evidence of two tapping speeds performed by Eurasian Wrynecks at their nest sites. Both speeds were found to occur in the two distant areas of Europe where observations were made. The faster form, given inside the cavity during courtship, also had on average three times more strikes per burst than the slower form, 
given to signal presence at the entrance. Our close observations established that all of the examples recorded were given in communication between breeding pairs. One recording captured a pair tapping simultaneously, one at the faster speed inside and one at the slower speed outside. Two exceptionally soft and short rolls did not establish any clear behavioural significance and hardly justified the use of the term 'drumming' in the discussion of acoustic signals for this species. A better understanding of the function of instrumental tapping used by Eurasian Wryneck, and indeed other woodpecker species, would require a more continuous observation of one or more pairs throughout their breeding cycle.

\section{Acknowledgements}

We would like to thank Danny Alder for his constructive comments and advice and Joanna Guske for help with translations. We also thank anonymous reviewers for their comments.

\section{References}

BirdLife International 2021. Species factsheet: Jynx torquilla. - http://www.birdlife.org

Blume, D. 1996. Schwarzspecht, Grünspecht, Grauspecht [Black, Green and Grey-headed Woodpeckers]. - Die Neue Brehm-Bucherei, Spektrum Akademischer Verlag, Heidelberg (in German)

Blume, D. \& Tiefenbach, J. 1997. Die Buntspechte: Gattung Picoides [The Spotted Woodpeckers: Genus Picoides]. - Westarp Wissenschaften, Magdeburg (in German)

Bussmann, J. 1941. Beitrag zur Kenntnis der Brutbiologie des Wendehalses Jynx torquilla torquilla L. [Contribution to the knowledge of the breeding biology of the Wryneck Jynx torquilla torquilla L.]. - Schweiz Arch Vogelkunde 1: 467-480. (in German)

Clements, J. F., Schulenberg, T. S., Iliff, M. J., Billerman, S. M., Fredericks, T. A., Sullivan, B. L. \& Wood, C. L. 2019. The eBird/Clements Checklist of Birds of the World. - v2019. Cornell, https://www.birds.cornell.edu/ clementschecklist/download

Cramp, S. (ed.) 1985. Handbook of the Birds of Europe, the Middle East and North Africa. The Birds of the Western Palearctic, Vol. 4. - OUP, Oxford

del Hoyo, J. \& Collar, N. J. 2014. HBW and BirdLife International Illustrated Checklist of the Birds of the World, Vol. 1. - Lynx Edicions, Barcelona

Florentin, J., Dutoit, T. \& Verlinden, O. 2016. Identification of European woodpecker species in audio recordings from their drumming rolls. - Ecological Informatics 35: 61-70. DOI: 10.1016/j.ecoinf.2016.08.006

Florentin, J., Turner, K., Rasmont, P., Gérard, M. \& Verlinden, O. in prep. Variants in tapping and drumming signals of European Woodpeckers.

Gill, F., Donsker, D. \& Rasmussen, P. (eds.) 2020. IOC World Bird List. - DOI: 10.14344/IOC.ML.11.1.

Glutz von Blotzheim, U. N. \& Bauer, K. M. (eds.) 1994. Handbuch der Vögel Mitteleuropas. Band 9., Columbiformes-Piciformes [Handbook of the Birds of Middle Europe, Vol. 9., Columbiformes-Piciformes]. - AULA-Verlag Gmbh, Wiesbaden (in German)

González, J. V., Gómez, J. R. \& Muñoz, B. 2002. El torcecuello. Determinación de la edad y el sexo, reproducción y fenología en el Noroeste peninsular ibérico [The Wryneck. determination of age, sex, reproduction and phenology in the northwest Iberian Peninsula]. - Sociedad Asturiana de Historia Natural y Ecología (in Spanish)

Goodge, W. R. 1972. Anatomical evidence for phylogenetic relationships among woodpeckers. - The Auk 89: 65-85.

Gorman, G. 2004. Woodpeckers of Europe. A study of the European Picidae. - Bruce Coleman, Chalfont St. Peter Gorman, G. 2014. Woodpeckers of the World: The Complete Guide. - Helm, London

Menzel, H. 1968. Der Wendehals (Jynx torquilla) [The Wryneck (Jynx torquilla)]. - Die Neue Brehm-Bücherei, Band 392. - A. Ziemsen Verlag, Wittenberg-Lutherstadt (in German) 
Puhlmann, E. 1914. Zur Brutgeschichte der Wendehalse [The breeding history of the Wryneck]. - Ornithologische Monatsschrift 39: 205-207. (in German)

Reichlin, T. S., Schaub, M., Menz, M. H. M., Mermod, M., Portner, P., Arlettat, R. \& Jenni, L. 2009. Migration patterns of Hoopoe Upupa epops and Wryneck Jynx torquilla: an analysis of European ring recoveries. Journal of Ornithology 150: 393-400. DOI: 10.1007/s10336-008-0361-3

Ruge, K. 1971. Beobachtungen am Wendehals Jynx torquilla [Observations on the Wryneck Jynx torquilla]. Ornithologische Beobachter 68: 9-33. (in German)

Ruge, K., Bastian, H-V. \& Bruland, W. 1988. Der Wendehals [The Wryneck]. Vogelkunde Bücherei 5. - Verlag Opus data Rottenburg (in German)

Short, L. L. 1982. Woodpeckers of the World. - Delaware Museum of Natural History, Greenville, Delaware

Short, L. L. 1988. - Jynx torquilla Eurasian Wryneck. - In: Fry, C. H., Keith, S. \& Urban, E. K. (eds.) The Birds of Africa, Vol. 3. - Academic Press, San Diego

Schneider, W. 1961. Tambourinage du Torcol [Drumming of the Wryneck]. - Nos Oiseaux 26: 50. (in French)

Turner, K. 2020. The structure and function of drumming in the Middle Spotted Woodpecker Dendrocoptes medius. - Acta Ornithologica 55: 129-138. DOI: 10.3161/00016454AO2020.55.1.013

Witherby, H. F., Jourdain, F. C. R., Ticehurst, N. F. \& Tucker, B. W. 1938. The Handbook of British Birds, Vol. 2. - Witherby, London

Wimmer, N. \& Zahner, V. 2010. Spechte - Leben in der Vertikalen [Woodpeckers - Life in the vertical]. - G. Braun Buchverlag, Karlsruhe (in German)

Winkler, H. \& Short, L. 1978. A comparative analysis of acoustical signals in Pied Woodpeckers (Aves, Picoides). - Bulletin of the American Museum of Natural History 160: 1-109.

Winkler, H., Christie, D. A. \& Nurney, D. 1995. Woodpeckers: A Guide to the Woodpeckers, Piculets and Wrynecks of the World. - Pica Press, Robertsbridge, UK.

Winkler, H. \& Christie, D. A. 2002. Family Picidae (Woodpeckers). - In: del Hoyo, J., Elliot, A. \& Sargatal, J. (eds.) Handbook of the Birds of the World, Vol. 7. - Lynx Edicions, Barcelona, p. 353.

Zabka, H. 1980. Zur funktionellen Bedeutung der Instrumentallaute europäischer Spechte unter besonderer Berücksichtigun von Dendrocopos major und Dendrocopos minor [The functional importance of the instrumental sounds of European woodpeckers with special reference to Dendrocopos major and Dendrocopos minor]. - Mitteilungen aus dem Zoologischen Museum in Berlin. 56 Supplementheft, Annalen für Ornithologie 4: 51-76. (in German with English Summary)

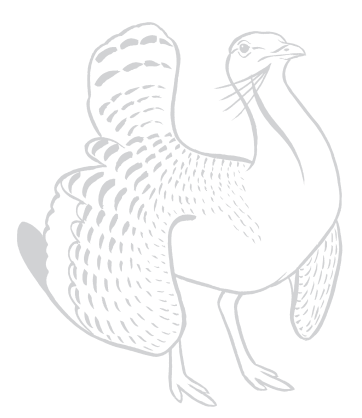

